\title{
Evaluation of Different Cucumber (Cucumis sativus L.) Hybrids for their Growth and Yield under Prayagraj Agro-Climatic Conditions
}

\author{
Adona Anna Shaju*, Urfi Fatmi and Devi Singh \\ Department of Horticulture, Naini Agriculture Institute, Sam Higginbottom University of \\ Agriculture, Technology and Sciences, Prayagraj 211007 (UP), India \\ *Corresponding author
}

\section{A B S T R A C T}

\begin{tabular}{l} 
Ke y w o r d s \\
$\begin{array}{l}\text { Cucumber, Growth, } \\
\text { Varieties, Yield }\end{array}$ \\
\hline Article Info \\
$\begin{array}{l}\text { Accepted: } \\
10 \text { November } 2020 \\
\text { Available Online: } \\
10 \text { December } 2020\end{array}$ \\
\hline
\end{tabular}

To evaluate different hybrids of cucumber for their growth and yield under Prayagraj Agro-climatic condition; a field experiment was conducted on the research farm of the Department of Horticulture, SHUATS, Prayagraj during rainy season 2019-2020. For the evaluation eleven hybrid varieties such as Chitra, NS 415, Manasi, Don, Shighra, JK Manali, Kohinoor, Ragini, Manish, Raaj and Himani are taken for the study in a Randomized Block Design with three replications in $1.5 \times 0.6 \mathrm{~m}^{2}$ plot. Early germination was observed in Kohinoor followed by Ragini recorded 4.25 and 4.33 days respectively. The study revealed that the maximum vine length $220.46 \mathrm{~cm}$ and $220.3 \mathrm{~cm}$ was reported in Ragini and Himani at an average taken for 30,60 and 90 days. The number of primary branches was maximum in Ragini 10.43 at 90 DAS. At 90 DAS the number of leaves was high in Ragini followed by Himani which was 73 and 72.10 respectively. Days to first female flower appearance and node to first female flower appearance was minimum seen in Kohinoor and that was about 32.55 and 4.9 respectively. Kohinoor was found to be the best variety for fruit length, weight, and diameter with $19.61 \mathrm{~cm}, 168.44 \mathrm{gm}$ and $4.01 \mathrm{~cm}$ respectively followed by Himani with $18.72 \mathrm{~cm}$ length $167.37 \mathrm{gm}$ weight and $3.89 \mathrm{~cm}$ diameter respectively. Kohinoor produced the maximum fruit yield/ha and the fruit yield was about $59.7 \mathrm{t}$ followed by Ragini $55.4 \mathrm{t} / \mathrm{ha}$. Among the different varieties studied, Kohinoor performed best for flower, fruit, germination, and yield characters. And the best varieties followed are Himani and V8 Rahina. The study revealed that, the hybrid varieties of cucumber provide high benefit to the farmers through easy cultivation, better stress tolerance, diseases resistance and higher yields.

\section{Introduction}

Cucumber (Cucumis sativus L., 2n = 14) belongs to Cucurbitaceae family, containing 118 genera with 825 species, it is one of the most important cucurbitaceous vegetable crops. They are cross pollinated crop and pollination is commonly fulfilled by honeybee. It is grown in summer season as well as in rainy season. It is a warm season crop mainly grown in tropical and subtropical regions. It requires a short period of time to 
mature. It is thermophilic and highly susceptible to frost. It is grown best in the temperature range between $18-30^{\circ} \mathrm{c}$. Cucumber can be grown on almost any kind of good soil, a light heavy and well-drained soil, which contains an abundance of organic matter, is favourable for growing cucumber.

Cucumbers are composed of $96 \%$ water, which may increase hydration and help you meet your daily fluid needs. It contains good amount of fibre, antioxidants, including flavonoids and tannins, which prevent the accumulation of harmful free radicals and may reduce the risk of chronic disease. Cucumbers are low in calories but high in water and several important vitamins and minerals. Eating cucumbers with the peel provides the maximum amount of nutrients. Cucumbers can be eaten fresh or pickled. They can be enjoyed as a low-calorie snack or used to add flavour in a variety of dishes, all of these may aid in weight loss. Test-tube and animal studies show that cucumber may help lower blood sugar and prevent diabetesrelated complications, although additional research is needed.

Cucumbers hold second place (after tomatoes) in fresh vegetable consumption. Cucumbers are cultivated by all governorates in a total area of about 40,000 feddans, mainly as a summer crop. The increasing demand for export makes cucumbers a choice crop for high economic return. New varieties and modern technological practices offer new yield records and have contributed to production of off-season crops. The productivity can be increase by manipulating in various factors i.e. environment, soil, production technology and protection from insect-pest and diseases. The main constrains for cucumber cultivation are irrigation facilities, labour, construction of adequate storage structures in view of the nature of the fruit, and pests and diseases control and management (Umeh and Onovo, 2015).
Hence, for increasing productivity of cucumber and the performance of varieties under particular agro-climatic conditions is essential. With a view to select a high yielding variety, a study was undertaken for its adoptability under Allahabad conditions.

\section{Materials and Methods}

The present investigation entitle "Evaluation of different cucumber hybrids for their growth and yield under Prayagraj Agro-climatic condition " was carried out during first week of August to last week of October the year 2019-20 at Horticulture Research Farm, Department of horticulture, Naini Agriculture Institute, Sam Higginbottom Institute of Agriculture Technology and Sciences, Prayagraj (U.P). The experiment was laid out in randomized block design with three replications on $1^{\text {st }}$ August 2019. The sowing was done on flat beds with spacing of $60 \mathrm{~cm}$ and $80 \mathrm{~cm}$ plant to plant and row to row respectively, each plot with 6 plants. Adopting the recommended cultivation practices for raising a healthy crop and stacking was given for vine climbing. Data's were recorded on all the important characters pertaining to the present study.

The pits were made and the seeds were sown, the distance between plant to plant and row to row was $0.6 \mathrm{~m}$ and $1 \mathrm{~m}$ respectively three seeds were sown in each pit with 1.5 to $2 \mathrm{~cm}$ depth. Thinning of seedling was done with in a period of three weeks and single healthy plant was maintained at each pit. The cultural practices such as irrigation weeding and plant protection measure were carried out uniformly as and when required.

\section{Varieties}

$\mathrm{V}_{1}-$ Chitra

$\mathrm{V}_{2}$. - Ns 415 
$\mathrm{V}_{3}-$ Manasi

$\mathrm{V}_{4}-$ Don

$\mathrm{V}_{5}$ - Shighra

$\mathrm{V}_{6}$ - Jk Manali

$\mathrm{V}_{7}-$ Kohinoor

$\mathrm{V}_{8}-$ Ragini

$\mathrm{V}_{9}-$ Manish

$\mathrm{V}_{10}-\mathrm{Raaj}$

\section{Results and Discussion}

\section{Vegetative growth parameters}

Vegetative growth parameters such as germination percentage, plant height (vine length), number of primary branches and number of leaves were influenced significantly amongst different hybrids under Prayagraj Agro-climatic condition.

The hybrid variety V11 'Himani' recorded the maximum plant height and number of leaves i.e. $220.46 \mathrm{~cm}$, L. N. Dongarwa et al., (2017) find out that for radish minimum height was recorded for Pusa Himani $(22.70 \mathrm{~cm})$ whereas the minimum plant height and number of leaves were noted in V3 'Manasi' i.e. 181.08 $\mathrm{cm}$ and 62.76 respectively.

The hybrid variety V8 Ragini recorded maximum number of primary branches i.e. 10.43 followed by V7 Kohinoor 9.69, whereas minimum number of primary branches was recorded in V5 Shighra i.e. 6.49

The germination percentage was high in $\mathrm{V7}$ Kohinoor followed by V8 Ragini i.e. 4.25 and 4.33 respectively, whereas the minimum germination percentage was recorded in V5 Shighra i.e. 6.25 (Fig. 1 and Table 1).

\section{Floral parameters}

Floral parameters like first male and female flower appearance, node to first male and female flower and male female ratio were influenced significantly amongst different hybrids under Prayagraj Agro-climatic condition.

The hybrid V7 Kohinoor reported the first male and female flower appearance at about 32.55 days and 36.99 days respectively whereas V6 JK Manali and V5 Shighra took maximum days i.e. about 38.87 days and 39.22 days respectively for male and female flower appearance.

Node at which first male flower appeared was noted in V8 Ragini i.e. 4.04 and first female flower appeared was noted in V7 Kohinoor i.e. 4.95, whereas the node at which first male and female flower appeared last was V4 Don i.e. about 6.28 and 6.73 respectively.

The male: female ratio was high in $\mathrm{V7}$ Kohinoor i.e. 6.32 followed by V11 Himani 6.00, whereas the minimum male: female ratio was recorded in V5 Shighra i.e. about 4.05 (Fig. 2 and Table 2).

\section{Yield parameter}

Yield parameters such as days to first picking, days to last picking, harvesting duration, fruit diameter, fruit length, fruit weight, average yield per plant, marketable fruit yield and average yield per hector influenced significantly amongst different hybrids under Prayagraj Agro-climatic condition. The hybrid V7 Kohinoor reported maximum days to first picking, maximum days to last picking and maximum harvesting duration i.e. about 44.89, 75.72 and 25.62 days respectively, whereas the minimum days was reported in V5 Shighra for both days to first picking and harvesting duration V. G. Lajurkar et al., (2017) reported first harvest noticed in hybrid Shighra (51.10 days) for cucumber. V4 Don reported the minimum days taken for last picking. The fruits of V7 Kohinoor were 
having the largest fruit diameter, fruit length and fruit weight i.e. about $4.01 \mathrm{~cm}, 19.61 \mathrm{~cm}$ and $168.44 \mathrm{gm}$ respectively, similar results have been reported by S. Vijay Kumar et al., (2018) who has reported that for garden pea higher pod length was recorded in Kohinoor$10(8.52 \mathrm{~cm})$ and the minimum fruit diameter, fruit length and weight was reported in V5 Shighra i.e. about $3.55 \mathrm{~cm}, 13.73 \mathrm{~cm}$ and 141.27 gm respectively (Fig. 3 and Table 3 ).

Table.1 Evaluation of different cucumber (Cucumis sativus L.) hybrids on their vegetative parameters at different levels

\begin{tabular}{|c|c|c|c|c|}
\hline Hybrids & $\begin{array}{c}\text { Day taken for } \\
\text { germination }\end{array}$ & $\begin{array}{c}\text { Plant } \\
\text { height }(\mathbf{c m})\end{array}$ & $\begin{array}{c}\text { Number of } \\
\text { primary branches } \\
\text { per plant }\end{array}$ & $\begin{array}{c}\text { Number of } \\
\text { leaves per plant }\end{array}$ \\
\hline V1-CHITRA & 5.1 & 200.21 & 8.9 & 69.5 \\
\hline V2-NS 415 & 5.5 & 195 & 8.4 & 66.3 \\
\hline V3-MANASI & 5 & 181.08 & 7.1 & 62.7 \\
\hline V4-DON & 5.6 & 186.6 & 7.5 & 63.9 \\
\hline V5-SHIGHRA & 6.2 & 198.18 & 6.4 & 65.4 \\
\hline V6-J K MANALI & 6.2 & 195.76 & 7.4 & 67.9 \\
\hline V7-KOHINOOR & 4.2 & 213.76 & 9.6 & 71.3 \\
\hline V8-RAGINI & 4.3 & 220.46 & 10.4 & 73 \\
\hline V9-MANISH & 4.6 & 200.26 & 7.3 & 68.6 \\
\hline V10-RAAJ & 4.6 & 210.77 & 7 & 70.3 \\
\hline V11-HIMANI & 4.4 & 220.3 & 9.5 & $\mathbf{0 . 8}$ \\
\hline CD(5\%) & $\mathbf{0 . 5}$ & $\mathbf{1 3 . 5}$ & $\mathbf{2 . 4}$ & \\
\hline
\end{tabular}

Table.2 Evaluation of different cucumber (Cucumis sativus L.) hybrids on their floral parameters at different levels

\begin{tabular}{|c|c|c|c|c|c|}
\hline Hybrids & $\begin{array}{c}\text { Number of } \\
\text { days to first } \\
\text { male flower } \\
\text { appearance }\end{array}$ & $\begin{array}{c}\text { Number of } \\
\text { days to first } \\
\text { female } \\
\text { flower } \\
\text { appearance }\end{array}$ & $\begin{array}{c}\text { Number of } \\
\text { nodes to } \\
\text { first male } \\
\text { flower } \\
\text { appearance }\end{array}$ & $\begin{array}{c}\text { Number of } \\
\text { nodes to } \\
\text { first female } \\
\text { flower } \\
\text { appearance }\end{array}$ & $\begin{array}{c}\text { Male : female } \\
\text { flower ratio }\end{array}$ \\
\hline V1-CHITRA & 34.8 & 37.2 & 4.4 & 5.4 & 5.7 \\
\hline V2-NS 415 & 35.2 & 38.7 & 5.2 & 6.3 & 4.7 \\
\hline V3-MANASI & 34.3 & 38.5 & 4.8 & 6.2 & 4.2 \\
\hline V4-DON & 35.93 & 39.2 & 6.3 & 6.7 & 4.5 \\
\hline V5-SHIGHRA & 36.9 & 39.2 & 5.9 & 6.4 & 4.1 \\
\hline V6-J K MANALI & 38.8 & 38.8 & 5.1 & 5.3 & 5.1 \\
\hline V7-KOHINOOR & 32.5 & 36.9 & 4.1 & 4.9 & 6.3 \\
\hline V8-RAGINI & 32.6 & 37.2 & 4 & 5.2 & 5.8 \\
\hline V9-MANISH & 33.3 & 38.8 & 5 & 5.6 & 5.6 \\
\hline V10-RAAJ & 34.8 & 38.7 & 4.4 & 5.4 & 5.4 \\
\hline V11-HIMANI & 32.8 & 37.1 & 4.2 & 5.3 & 6 \\
\hline CD(5\%) & $\mathbf{0 . 5}$ & $\mathbf{0 . 6}$ & $\mathbf{0 . 5}$ & $\mathbf{0 . 5}$ & $\mathbf{0 . 2}$ \\
\hline & & & & & \\
\hline
\end{tabular}


Table.3 Evaluation of different cucumber (Cucumis sativus L.) hybrids on their yield parameters at different levels

\begin{tabular}{|c|c|c|c|}
\hline Hybrids & $\begin{array}{c}\text { Fruit per } \\
\text { plant }(\mathbf{k g})\end{array}$ & $\begin{array}{c}\text { Average yield } \\
\text { per hector } \\
\text { (t/ha) }\end{array}$ & $\begin{array}{c}\text { Marketable } \\
\text { fruit yield } \\
\text { (t/ha) }\end{array}$ \\
\hline V1-CHITRA & 0.9 & 33.1 & 24.8 \\
\hline V2-NS 415 & 1.3 & 50 & 37.5 \\
\hline V3-MANASI & 0.8 & 29.2 & 21.8 \\
\hline V4-DON & 0.6 & 25.9 & 19.4 \\
\hline V5-SHIGHRA & 0.7 & 22.3 & 16.7 \\
\hline V6-J K & 1.2 & 43.5 & 32.6 \\
\hline MANALI & & & \\
\hline V7- & 1.6 & 59.7 & 44.3 \\
\hline KOHINOOR & & & \\
\hline V8-RAGINI & 1.5 & 55.4 & 41.6 \\
\hline V9-MANISH & 1.1 & 37.8 & 28.3 \\
\hline V10-RAAJ & 1.3 & 47.5 & 35.6 \\
\hline V11-HIMANI & 1.4 & 51.5 & 38.6 \\
\hline CD (5\%) & $\mathbf{1 . 5}$ & $\mathbf{2}$ & $\mathbf{1 . 5}$ \\
\hline
\end{tabular}

Fig.1 Evaluation of different cucumber (Cucumis sativus L.) hybrids on their vegetative parameters at different levels

\section{Growth Parameters}

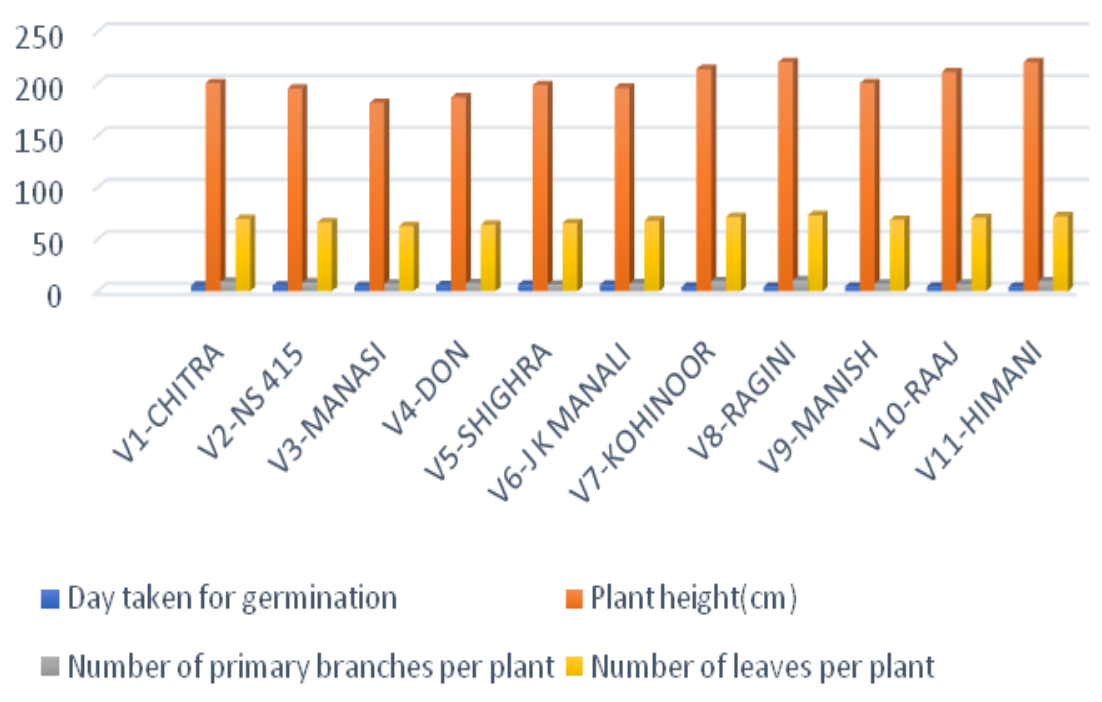


Fig.2 Evaluation of different cucumber (Cucumis sativus L.) hybrids on their floral parameters at different levels

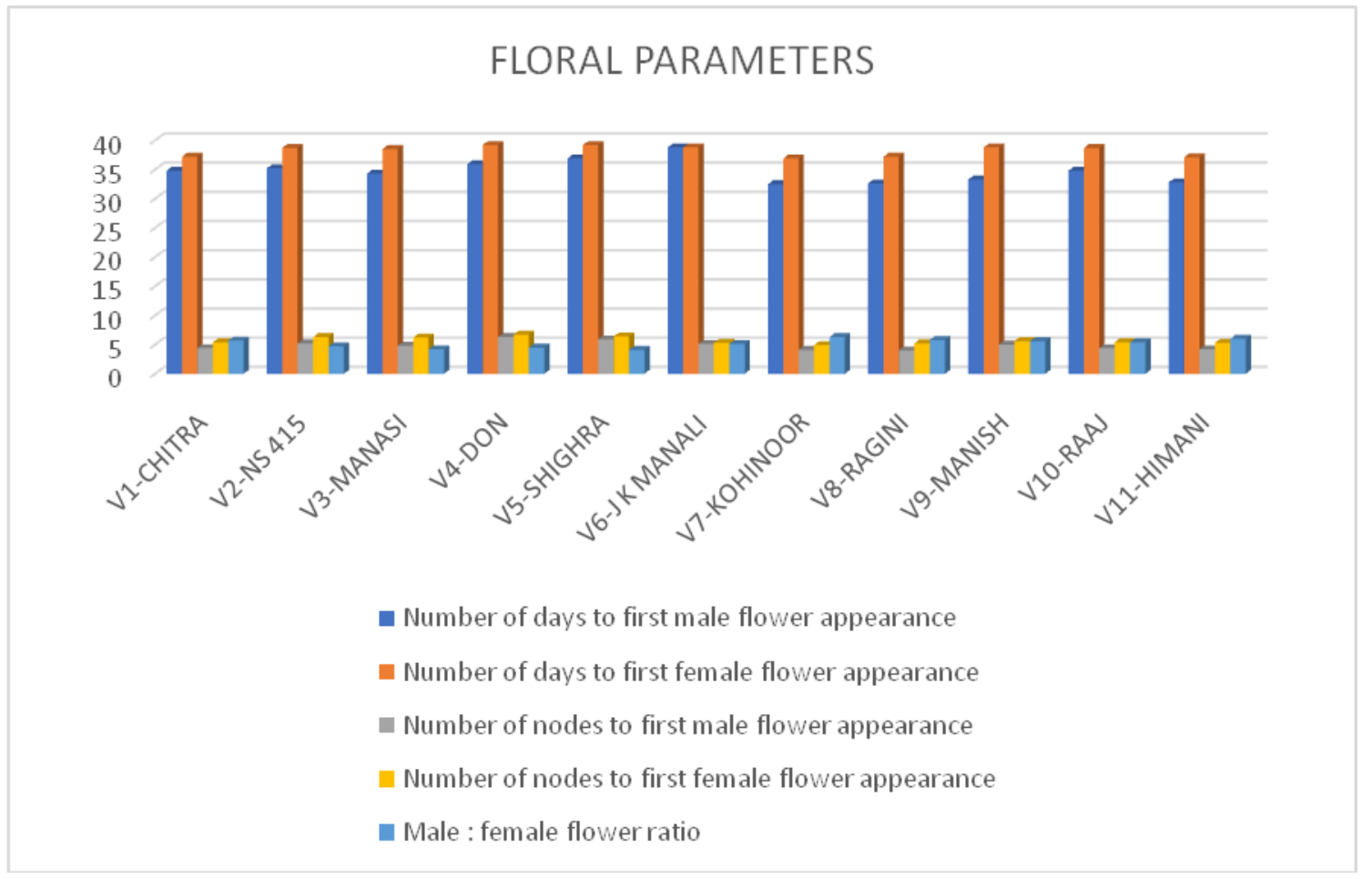

Fig.3 Evaluation of different cucumber (Cucumis sativus L.) hybrids on their yield parameters at different levels

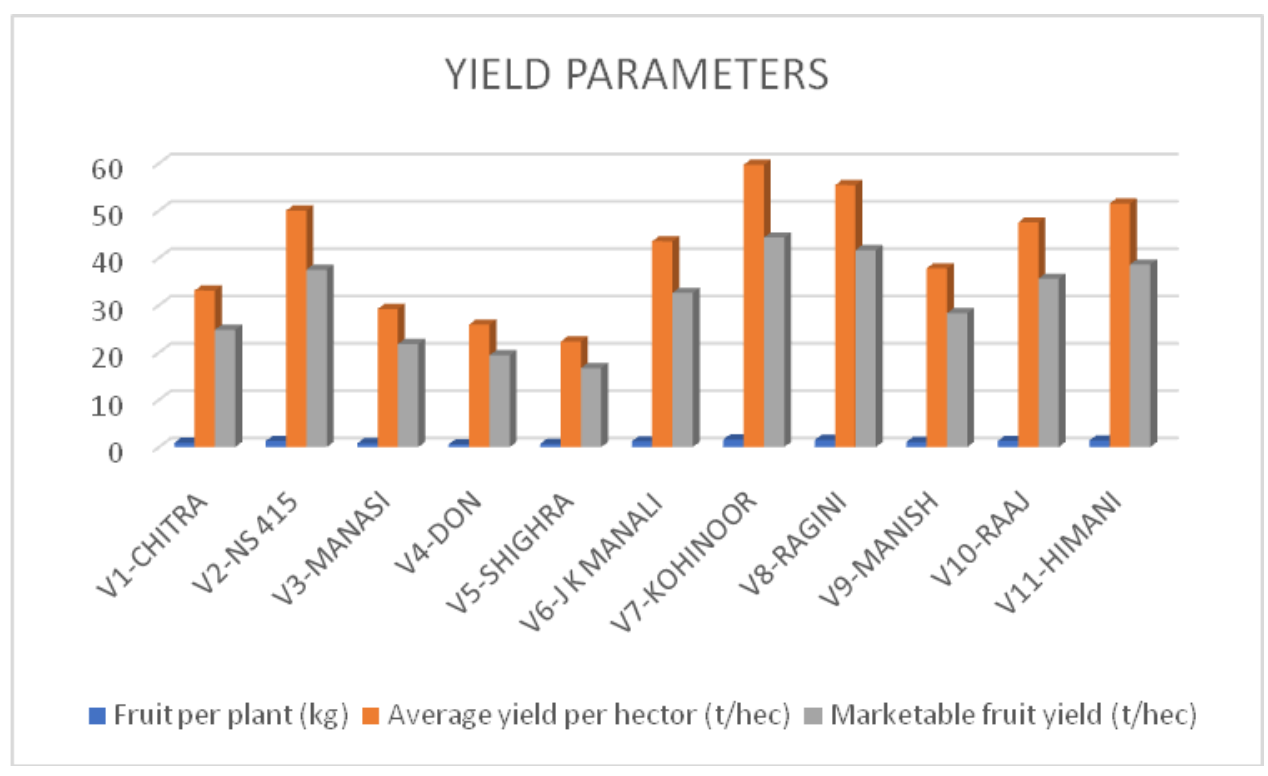

The hybrid V7 Kohinoor was having the maximum yield per plant and maximum marketable fruit yield per hectare i.e. 1.66 $\mathrm{kg} / \mathrm{plant}$ and $44.32 \mathrm{t} / \mathrm{ha}$ followed by $\mathrm{V} 8$
Ragini $1.5 \mathrm{~kg} /$ plant and $41.6 \mathrm{t} / \mathrm{ha}$ whereas the minimum yield and marketable fruit yield was recorded in V4 Don i.e. about $0.62 \mathrm{~kg} /$ plant and $16.74 \mathrm{t} / \mathrm{ha}$. 
Average yield per hectare was also high for V7 Kohinoor i.e. about and $59.76 \mathrm{t} / \mathrm{ha}$ followed by V8 Ragini $55.4 \mathrm{t} / \mathrm{ha}$ whereas the minimum yield was recorded in V4 Don $22.32 \mathrm{t} / \mathrm{ha}$.

In conclusion, the hybrids of cucumber cultivated in Prayagraj agro-climatic condition displayed significant variations in vegetative development, floral parameters and yield characters, offering a lot of scope to exploit their horticultural potential. For open cultivation, Kohinoor (V7) hybrid recorded the highest fruit yield per plant $(1.66 \mathrm{~kg})$, highest fruit yield per hectare (59.76 t/ha), early fruit maturity (44.89 days), minimum days to germination (4.25 days), minimum days to first female flower appearance (36.99 days), highest net return (Rs. 1,60,183) and $\mathrm{B}: \mathrm{C}$ ratio (3.50:1) followed by Ragini (V8). Therefore, the cucumber hybrid Kohinoor and Ragini could be economically good option for small and marginal farmers for the cultivation in Prayagraj agro-climatic condition.

\section{Acknowledgement}

My proud privilege to express a deep sense of gratitude to my advisor Dr. Urfi Fatmi, Assistant Professor, Department of Horticulture, Naini Agricultural Institute, SHUATS, whose generous help, untiring guidance, supervision, suggestions and positive attitude during my work. I express a deep sense of gratitude to all the teaching staff members of Department of Horticulture Dr. Vijay Bahadur, Dr. S. S. Saravanan, Prof. (Dr.) V. M. Prasad, Dr. Samir E. Topno, Mr. Deepanshu, Dr. Devi singh, Mr. Deepak Lal, and Dr. Anita Kerketta for their persistent help and valuable information's regarding the work.

\section{References}

Ahmed, M.; Hamid, A. and Akbar, Z. 2004. Growth and yield Performance of Six
Cucumber (Cucumis sativus L.) Cultivars under Agro- Climatic Conditions of Rawalakot, Azad Jammu and Kashmir. International Journal of Agriculture and Biology. 6(2): 393-400.

Ananthan, M. and C.M. Pappiah, 1997. Combining ability and correlation studies in cucumber (Cucumis sativus L.). South Indian Hort., 45: 75-58

Choudhury B. (2000). Vegetable production, National Book Trust pub. New Delhi, 2000, 150-151.

Emmanuel Mremaa and Amon P. Maerereb (2018). Growth and yield performance of cucumber during dry and wet seasons under tropical conditions. International journal of vegetable science, 5; 54-62.

Enwezor, W. O. Ohiri, A.O, Opuwaribo, E.E. and Udo, E .J. (1991) A literature review of soil fertility investigation in Nigeria. FMA and NR, Lagos. Pp. 53100.

Fonsah, E.G. and Wolfe, K. (2002) Wholesales and distribution outlook for and vegetables produced in Georgia G.FVGA News Vo17, No41.Pp 47-56.

Foster, R., Egel, C.and Taber, H. (1995) the cucurbit production guide for commercial growers, Pardue University Co-operation Extension Service.

Hamid, A., J.D. Bloch and K. Naeemullah, 2002. Performance studies on six cucumber genotypes under local conditions of Swat. Int. J. Agri. Biol., 4: 491-2

Levetin, E.K. and Mrnahoii, C. (2003) Plants and society (3rd ed.) M.C. Graw Hill, Dubuque, Lowe, U.S.A.

Maggs-Kölling GL, Madsen S, Christiansen JL. (2000). A phenetic analysis of morphological variation in Citrullus lanatus in Namibia. Genetic Resources and Crop Evolution. 2000; 47:385-393.

Manu, K. K., (2014) Genetic variability and divergence studies in oriental pickling melon (Cucumis Melo Var. Conomon). 
M. Sc. Thesis, University of Horticultural Sciences, Bagalkot. http://nhb.gov.in/.

Sharma, A.K., Goel, K. Rajiner and R. Kumar, 2000. Performance of cucumber cultivar under protected cultivation. Himachal. J. Agric. Res., 26: 175-7.

Vijayakumari, P., More, T. A. and Seshadri, V. S., (2005). Evaluation of gynoecious F1 hybrids for horticultural characters in cucumber. Veg. Sci., 18 (2): 167-176 (2005).

Yogesh, C., Yadav, S., K, Bisen, Band. and Dixit, S.K. 2009. Genetic variability, heritability, and genetic advance for some traits in cucumber. Indian Journal of Horticulture. 66(4): 488-491.

\section{How to cite this article:}

Adona Anna Shaju, Urfi Fatmi and Devi Singh. 2020. Evaluation of Different Cucumber (Cucumis sativus L.) Hybrids for their Growth and Yield under Prayagraj Agro-Climatic Conditions. Int.J.Curr.Microbiol.App.Sci. 9(12): 1194-1201.

doi: https://doi.org/10.20546/ijcmas.2020.912.146 